\title{
Hydrochemical analysis and evaluation of groundwater quality in El Eulma area, Algeria
}

\author{
Lazhar Belkhiri • Lotfi Mouni
}

Received: 4 September 2011/ Accepted: 7 February 2012/Published online: 28 February 2012

(C) The Author(s) 2012. This article is published with open access at Springerlink.com

\begin{abstract}
The groundwater sources in the El Elma plain have been evaluated for their chemical composition and suitability for irrigation uses. Cluster analysis in Q-mode resulted in three major water types $\left(\mathrm{HCO}_{3}{ }^{-}-\mathrm{Ca}^{2}{ }^{2+}\right.$ dominated, $\mathrm{Cl}^{-}-\mathrm{HCO}_{3}{ }^{-}-\mathrm{Ca}^{2+}$-dominated and $\mathrm{Cl}^{-}-\mathrm{Ca}^{2+}-\mathrm{Na}^{+}-$ dominated) for the groundwater. The US salinity diagram illustrates that most of the groundwater samples fall in C3S1 quality with high salinity hazard and low sodium hazard. Based on RSC values, all the samples of the three groups had values less than 1.25 and were good for irrigation.
\end{abstract}

Keywords Hydrochemical - Q-mode cluster analysis · Irrigation · El Eulma area $\cdot$ Algeria

\section{Introduction}

Quality of groundwater is equally important to its quantity owing to the suitability of water for various purposes. Water quality analysis is an important issue in groundwater studies. Variation of groundwater quality in an area is a function of physical and chemical parameters that are greatly influenced by geological formations and anthropogenic activities (Belkhiri et al. 2010).

The hydrochemical study reveals the quality of water that is suitable for drinking, agriculture and industrial

\section{Belkhiri $(\square)$}

University of Batna, 05000 Batna, Algeria

e-mail: BELKHIRI_Laz@yahoo.fr

\section{Mouni}

Département des Sciences Techniques, Institut des Sciences, Université Akli Mohand Oulhadj, Bouira, Algeria purposes and helps in understanding the change in quality due to rock-water interaction or any type of anthropogenic influence (Kelley 1940; Wilcox 1948). The chemical parameters of groundwater play a significant role in classifying and assessing water quality. It was observed that the criteria used in the classification of waters for a particular purpose considering the individual concentration may not find its suitability for other purposes and better results can be obtained only by considering the combined chemistry of all the ions rather than individual or paired ionic characters (Handa 1964, 1965; Hem 1985). Chemical classification also throws light on the concentration of various predominant cations, anions and their interrelationships.

The present work had the objective of understanding the spatial distribution of hydrochemical constituents of groundwater related to its suitability for agriculture and domestic use and application of cluster analysis.

\section{Study area}

The study area is located in the East of Algeria (Fig. 1). Most of its inhabitants are concentrated in the town of El Eulma with more than 30,000 inhabitants working mainly in the production of cereals (barley, corn). The climate of the study area is considered to be semi-arid region, with an annual precipitation being approximately $421 \mathrm{~mm}$. The rainy season extends from October to May, with a maximum rainfall during December and March of each year. The mean monthly temperature varies between -3 and $38^{\circ} \mathrm{C}$, the mean annual temperature of $15^{\circ} \mathrm{C}$. The vegetation of the study area is characterized by grasses and herbs. Soils are generally sandy to clayey in texture and mostly classified as arid-sol and are calcareous. Mineralogically, most of the soils are dominated by kaolinite, illite, 


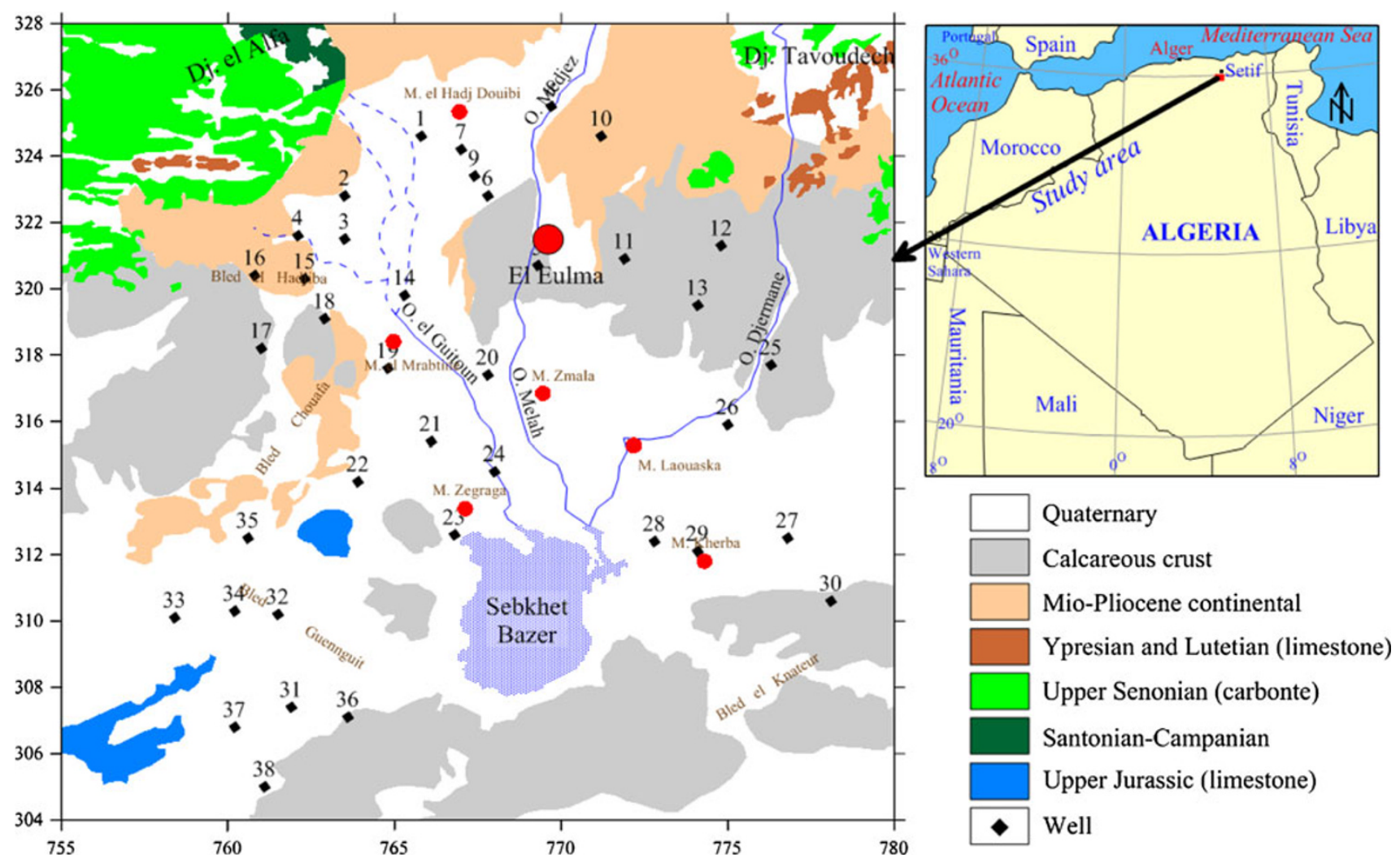

Fig. 1 Location map of the study area showing the sampling sites

smectite, and chlorite, typical for most arid and semi-arid soils. The presence of smectite suggests specific sites for sodium adsorption.

Rocks and unconsolidated deposits in the area can be divided into three geologic units (Savornin 1920; Galcon 1967; Guiraud 1973; Vila 1980): (1) upper Cretaceous (Senonian), (2) Eocene and (3) Mio-Plio-Quaternary. Senonian (upper Cretaceous) is generally found in the northern part of the study area. Senonian units composed of Santonian-Campanian formation and upper Senonian formation. These formations consist of various rocks with differing compositions including limestone and marl of about $550 \mathrm{~m}$ thick. Eocene units are composed of Ypresian-Lutetian formation (Fig. 1). Eocene rocks consist of a succession of marine, limestone and silt of about $80 \mathrm{~m}$ thick. The Mio-Plio-Quaternary is a heterogeneous continental detrital sedimentation. The study area is situated in the alluvial plain of the Mio-Plio-Quaternary. Shallow groundwater mainly occurs at $5-80 \mathrm{~m}$ below the surface. Groundwater is recharged by vertically infiltrating meteoric water in the basin and by stream water coming from different reliefs surrounding the inter-mountainous depression of El Eulma. The pumping tests on different wells showed high transmissivity $\left(10^{-3} \mathrm{~m}^{2} / \mathrm{s}\right)$ indicating high yields.

\section{Materials and methods}

Sample collection

A set of 38 groundwater samples was analyzed for 11 physical and chemical parameters comprising major ion concentrations $\left(\mathrm{Ca}^{2+}, \mathrm{Mg}^{2+}, \mathrm{Na}^{+}, \mathrm{K}^{+}, \mathrm{Cl}^{-}, \mathrm{SO}_{4}{ }^{2-}\right.$, $\mathrm{HCO}_{3}{ }^{-}, \mathrm{NO}_{3}{ }^{-}$), electrical conductivity (EC), temperature and $\mathrm{pH}$. The samples were collected in four acid-washed polypropylene containers from wells located in the El Eulma aquifer, East of Algeria (Fig. 1) after pumping for $10 \mathrm{~min}$ to remove stored water in the wells. Each sample was immediately filtered using $0.45 \mu \mathrm{m}$ filters of acetate cellulose and was transferred into $100 \mathrm{ml}$ polyethylene bottles. The samples were immediately acidified, bringing down the $\mathrm{pH}$ to $<2$ by the addition of Merck ${ }^{\mathrm{TM}}$ ultrapure nitric acid ( $5 \mathrm{ml} 6 \mathrm{~N} \mathrm{HNO}_{3}$ ), and were used for cations' (i.e., alkaline earth and alkali metals) analysis. Samples for anions' analysis were collected into $250 \mathrm{~cm}^{3}$ polyethylene bottles without preservatives and were stored in an ice chest at a temperature of $<4^{\circ} \mathrm{C}$ and later transferred to the laboratory and stored in a refrigerator at a temperature of $<4^{\circ} \mathrm{C}$ until analyzed (within 1 week). Immediately after sampling, temperature, $\mathrm{pH}$ and electrical conductivity (EC) were measured in the field using a multi-parameter WTW 
(P3 MultiLine pH/LF-SET). Subsequently, the samples were analyzed in the laboratory for their chemical constituents such as $\mathrm{Ca}^{2+}, \mathrm{Mg}^{2+}, \mathrm{Na}^{+}, \mathrm{K}^{+}, \mathrm{Cl}^{-}, \mathrm{SO}_{4}{ }^{2-}, \mathrm{HCO}_{3}{ }^{-}$and $\mathrm{NO}_{3}{ }^{-}$, using standard methods as suggested by the American Public Health Association (APHA 1989, 1995a, 1995b). Concentrations of $\mathrm{Ca}^{2+}$ and $\mathrm{Mg}^{2+}$ were estimated titrimetrically using 0.05 and $0.01 \mathrm{NEDTA}$ and those of $\mathrm{HCO}_{3}{ }^{-}$and $\mathrm{Cl}^{-}$by $\mathrm{H}_{2} \mathrm{SO}_{4}$ and $\mathrm{AgNO}_{3}$ titration, respectively. Concentrations of $\mathrm{Na}^{+}$and $\mathrm{K}^{+}$were measured using a flame photometer (Model: Systronics Flame Photometer 128) and those of sulfates $\mathrm{SO}_{4}{ }^{2-}$ by turbidimetric method (Clesceri et al. 1998). Nitrates, $\mathrm{NO}_{3}{ }^{-}$, were analyzed by colorimetry with a UV-vis spectrophotometer (Rowell 1994). Standard solutions for the above analyses were prepared from the respective salts of analytical reagents grades.

\section{Cluster analysis}

Multivariate statistical techniques, such as factor analysis or principal component analysis, provide more insight into the underlying structure of a data set, the use of these techniques might require further analyses to identify distinct groups. Cluster analysis (hierarchical clustering; Davis 1986), on the other hand, is a useful way of objectively organizing a large data set into groups on the basis of a given set of characteristics. This can ultimately assist in the recognition of potentially meaningful patterns (Swanson et al. 2001).

To identify possible groups and relationships among the samples analyzed based on major chemical compositions, ion species $\mathrm{Ca}^{2+}, \mathrm{Mg}^{2+}, \mathrm{Na}^{+}, \mathrm{K}^{+}, \mathrm{Cl}^{-}, \mathrm{SO}_{4}{ }^{2-}, \mathrm{HCO}_{3}{ }^{-}$ and $\mathrm{NO}_{3}{ }^{-}$were considered as variables for application in Q-mode cluster analysis. The clustering procedure was performed by the Ward's linkage method with the Euclidean distance as a measure of similarity of samples using the software STATISTICA ${ }^{\circledR}$ (1998).

\section{Results and discussion}

Groundwater chemistry

Table 1 presents the descriptive summary of all the parameters analyzed, along with their corresponding WHO standard limits. The electrical conductivity of groundwater samples ranges from 608 to $3,577 \mu \mathrm{S} / \mathrm{cm}$ with a mean value of $1,431 \mu \mathrm{S} / \mathrm{cm}$. The salinity increases in the direction of groundwater flow from north to south. The $\mathrm{pH}$ ranges between 7.8 and 8.5 with a mean value of 8.13 (Table 1), which shows that the groundwater of the study area is of alkaline nature. The mean temperature of groundwater samples was $11.16^{\circ} \mathrm{C} . ~^{-} \mathrm{Cl}^{-}$and $\mathrm{HCO}_{3}{ }^{-}$are the major anions and $\mathrm{Ca}^{2+}$ and $\mathrm{Mg}^{2+}$ are the major cations in shallow groundwater in El Eulma plain. The relative abundance of the ions was in the order of $\mathrm{Ca}^{2+}>\mathrm{Na}^{2+}>$ $\mathrm{Mg}^{2+}>\mathrm{K}^{+}$(on molar basis) and $\mathrm{Cl}^{-}>\mathrm{HCO}_{3}{ }^{-}>$ $\mathrm{SO}_{4}{ }^{2-}>\mathrm{NO}_{3}{ }^{-}$(Table 1). The maximum $\mathrm{Ca}^{2+}$ and $\mathrm{Mg}^{2+}$ concentrations of 288.6 and $74.13 \mathrm{mg} / \mathrm{l}$, respectively, are, however higher than their respective WHO (2006) standards of 75 and $30 \mathrm{mg} / \mathrm{l}$. The source of calcium and magnesium in the groundwater could be limestone and dolomite in the sedimentary rocks. The mean sodium and potassium concentrations in the groundwater are 105.69 and $4.54 \mathrm{mg} / \mathrm{l}$, respectively. The presence of bicarbonate ions $\mathrm{HCO}_{3}{ }^{-}$in the groundwater might have derived from carbon dioxide of the atmosphere, soils and by dissolution of carbonate rocks. Bicarbonate ion represents the second dominant anion in the study area. The concentration of $\mathrm{HCO}_{3}{ }^{-}$in most of northern part of the study reaches to about $366.1 \mathrm{mg} / \mathrm{l}$. Most $\mathrm{Cl}^{-}$in the groundwater is from three sources including ancient seawater entrapped in sediment, solution of halite and related minerals in evaporate deposits in the region. The chloride value in the study area ranges between 49.63 and $753.7 \mathrm{mg} / \mathrm{l}$. The occurrences of sulfate ions in the investigated water could be due to sedimentary rocks such as gypsum $\left(\mathrm{CaSO}_{4}, 2 \mathrm{H}_{2} \mathrm{O}\right)$ and anhydrite $\left(\mathrm{CaSO}_{4}\right)$. Further addition of sulfates to the groundwater might have come from the breakdown of organic matters in the soil, and from addition of leachable sulfates in fertilizers of the intensively cultivated areas in El Eulma plain. The value of $\mathrm{SO}_{4}{ }^{2-}$ in the study area ranges between 36.02 and $278.6 \mathrm{mg} / \mathrm{l}$. Almost $42 \%$ of the samples exceeded the desirable limit of $\mathrm{Cl}^{-}(250 \mathrm{mg} / \mathrm{l})$, but only $18.4 \%$ of them exceeded the desirable limit of $\mathrm{SO}_{4}{ }^{2-}$ (250 mg/l) (WHO 2006). Most samples exceeded the desirable limit of $\mathrm{NO}_{3}{ }^{-}$for drinking water $(50 \mathrm{mg} / \mathrm{l})$ (WHO 2006). In the study area, samples with high $\mathrm{NO}_{3}{ }^{-}$

Table 1 Chemical summary of shallow groundwater in the study area

\begin{tabular}{lrrllllllrrrr}
\hline & EC & \multicolumn{1}{c}{$T$} & $\mathrm{pH}$ & $\mathrm{Ca}^{2+}$ & $\mathrm{Mg}^{2+}$ & $\mathrm{Na}^{+}$ & $\mathrm{K}^{+}$ & $\mathrm{Cl}^{-}$ & $\mathrm{SO}_{4}{ }^{2-}$ & $\mathrm{HCO}_{3}{ }^{-}$ & $\mathrm{NO}_{3}{ }^{-}$ \\
\hline Min & 608 & 7.9 & 7.8 & 60.12 & 10.09 & 25.29 & 1.56 & 49.63 & 36.02 & 122 & 8.68 \\
Max & 3,577 & 14.9 & 8.5 & 288.6 & 74.13 & 451.7 & 9.38 & 753.7 & 278.6 & 366.1 & 161.2 \\
Mean & 1,431 & 11.16 & 8.13 & 141.71 & 33.1 & 105.69 & 4.54 & 219.65 & 152.98 & 228.32 & 73.59 \\
SD & 620 & 2.04 & 0.19 & 53.99 & 17.51 & 90.47 & 2.1 & 164.53 & 59.17 & 62.13 & 37.67 \\
Cv & 43 & 18.29 & 2.38 & 38.1 & 52.91 & 85.6 & 46.36 & 74.91 & 38.68 & 27.21 & 51.19 \\
\hline
\end{tabular}

All values are in mg/l except $\mathrm{pH}, T\left({ }^{\circ} \mathrm{C}\right)$ and $\mathrm{EC}(\mu \mathrm{S} / \mathrm{cm})$. WHO (2006) 
values were mainly those collected near urban areas. The high concentration of $\mathrm{NO}_{3}{ }^{-}$is likely to be related to wastewater leakage from industrial activities, urbanization and agricultural practices. $\mathrm{NO}_{3}{ }^{-}$concentration, reaching a maximum of $161.2 \mathrm{mg} / 1$, is also high due to the intensive agricultural practices.

\section{Cluster analysis}

The output of the Q-mode cluster analysis is given as a dendrogram (Fig. 2). Three preliminary groups are selected based on visual examination of the dendogram, each representing a hydrochemical facies (Table 2).

The first group of waters, group 1, has low salinity (mean $\mathrm{EC}=937 \mu \mathrm{S} / \mathrm{cm})$ and abundance orders (meq/l) $\mathrm{Ca}^{2+}>\mathrm{Na}^{+} \approx \mathrm{Mg}^{2+}>\mathrm{K}^{+}$and $\mathrm{HCO}_{3}{ }^{-}>\mathrm{Cl}^{-}>$ $\mathrm{SO}_{4}{ }^{2-}>\mathrm{NO}_{3}{ }^{-}$(Fig. 3). These waters are classified as $\mathrm{HCO}_{3}{ }^{-}$-alkaline earth water type. Group 2 is made up of water samples wherein the cation composition was dominated by $\mathrm{Ca}^{2+}$ and $\mathrm{Na}^{2+}$, with anion composition varying from dominantly $\mathrm{Cl}^{-}$to dominantly $\mathrm{HCO}_{3}{ }^{-}$plus $\mathrm{SO}_{4}{ }^{2-}$ (Fig. 3). EC values (mean 1,479 $\mu \mathrm{S} / \mathrm{cm}$ ) are significantly greater than those of group 1, reflecting a more effective weathering process. Group 3, made up of eight water

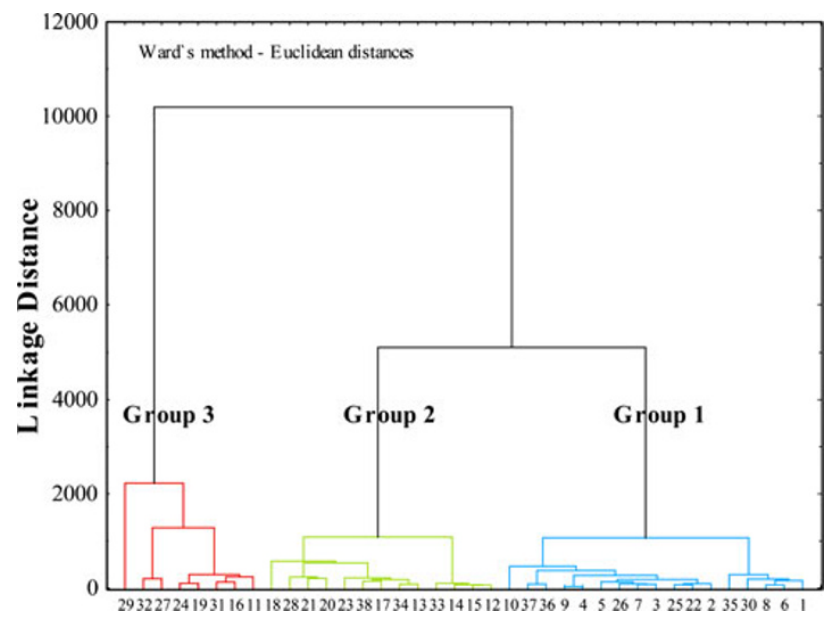

Fig. 2 Q-mode cluster analysis. Dendrogram for 38 samples and seven chemical variables samples, has a salinity range $(2,016<\mathrm{EC}<3,577 \mu \mathrm{S} / \mathrm{cm}$; mean $2,403 \mu \mathrm{S} / \mathrm{cm}$ ) overlapping those of the former two groups (G1 and G2). On the basis of overall chemical composition, characterized by ion abundances $\mathrm{Ca}^{2+} \approx$ $\mathrm{Na}^{+}>\mathrm{Mg}^{2+}>\mathrm{K}^{+}$and $\mathrm{Cl}^{-}>\mathrm{SO}_{4}{ }^{2-}>\mathrm{HCO}_{3}{ }^{-}>\mathrm{NO}_{3}{ }^{-}$, these waters are classified as $\mathrm{Cl}^{-}-\mathrm{Ca}^{2+}-\mathrm{Na}^{+}$type (Fig. 3). The most pronounced characteristic of this group is the increase in the $\mathrm{Cl}^{-}$content (Fig. 4).

Irrigation water quality

The suitability of groundwater for agricultural purposes depends on the effect of mineral constituents of water on both plants and soil. Effects of salts on soils causing changes in soil structure, permeability and aeration indirectly affect plant growth. Wilcox (1955) and US Salinity

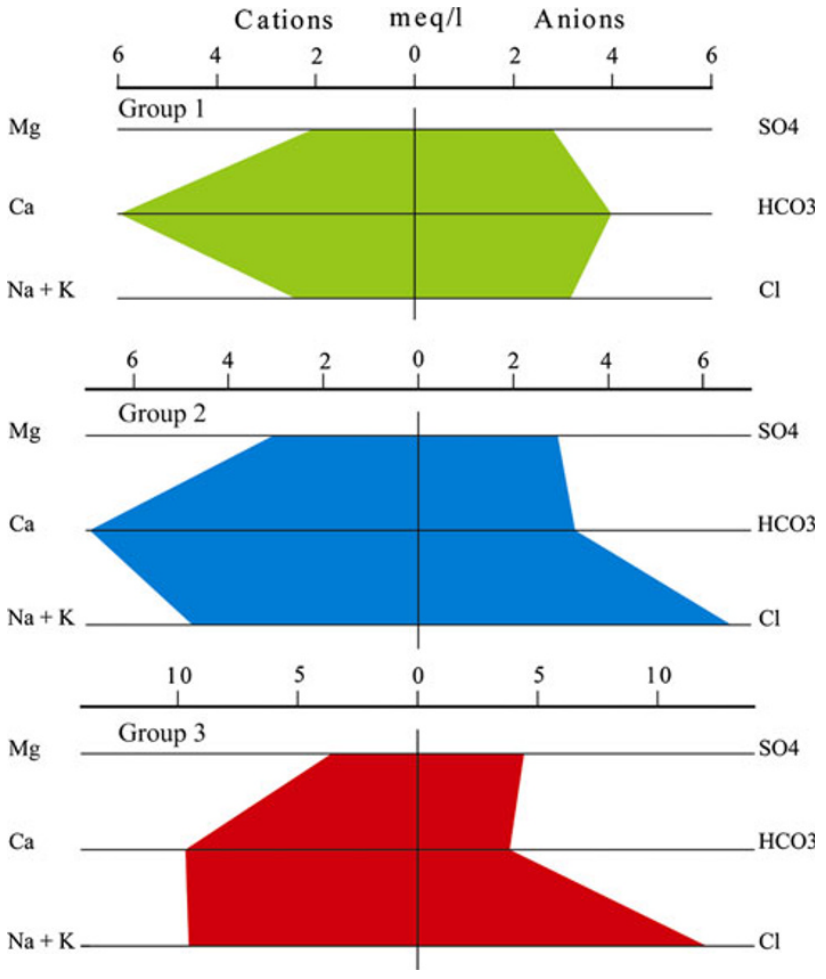

Fig. 3 Stiff diagram for water samples

Table 2 Mean concentrations of the major chemical parameters of the three main water groups

\begin{tabular}{lrllllllllll}
\hline & EC & $T$ & $\mathrm{pH}$ & $\mathrm{Ca}^{2+}$ & $\mathrm{Mg}^{2+}$ & $\mathrm{Na}^{+}$ & $\mathrm{K}^{+}$ & $\mathrm{Cl}^{-}$ & $\mathrm{SO}_{4}^{2-}$ & $\mathrm{HCO}_{3}{ }^{-}$ & $\mathrm{NO}_{3}{ }^{-}$ \\
\hline Group 1 & 937 & 11.36 & 8.17 & 119.56 & 25.06 & 53.21 & 3.98 & 111.75 & 134.1 & 244.37 & 60.03 \\
Group 2 & 1,479 & 11.05 & 8.18 & 138.74 & 37.09 & 106.8 & 4.3 & 233.51 & 140.63 & 202.3 \\
Group 3 & 2,403 & 10.93 & 7.99 & 193.58 & 43.69 & 215.4 & 6.11 & 426.41 & 213.19 & 236.48 & 76.5 \\
\hline
\end{tabular}

Group 1: 1-2-3-4-5-6-7-8-9-10-22-25-26-30-35-36 (17 wells)

Group 2: 12-13-14-15-17-18-20-21-23-28-33-34-38 (13 wells)

Group 3: 11-16-19-24-27-29-31-32 (08 wells) 
Laboratory Staff (1954) proposed irrigational specifications for evaluating the suitability of water for irrigation use. There is a significant relationship between sodium adsorption ratio

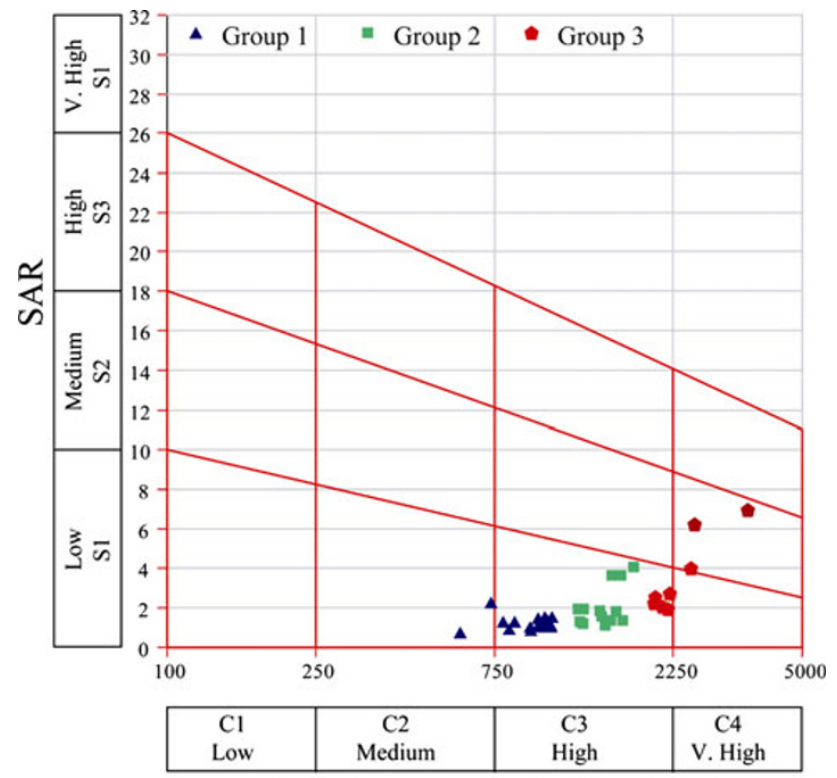

Electrical conductivity $(\mu \mathrm{S} / \mathrm{cm})$

Fig. 4 US salinity diagram for classification of irrigation waters

Table 3 Values of SAR, Na\% and RSC in the groundwater

\begin{tabular}{crrrr}
\hline & Min & Max & Mean & SD \\
\hline Group 1 & & & & \\
SAR & 0.71 & 2.21 & 1.16 & 0.36 \\
Na\% & 16.12 & 40.27 & 22.14 & 5.71 \\
RSC & -12.46 & -1.58 & -4.14 & 2.58 \\
Group 2 & & & & \\
SAR & 1.13 & 4.07 & 2.08 & 1.02 \\
Na\% & 18.84 & 49.64 & 30.40 & 9.48 \\
RSC & -12.53 & -4.20 & -6.66 & 2.29 \\
Group 3 & & & & \\
SAR & 1.92 & 6.95 & 3.58 & 1.97 \\
Na\% & 26.77 & 55.07 & 38.49 & 11.03 \\
RSC & -13.00 & -6.40 & -9.38 & 2.41 \\
\hline
\end{tabular}

(SAR) values for irrigation water and the extent to which sodium is adsorbed by the soils. If water used for irrigation is high in sodium and low in calcium, the cation exchange complex may become saturated with sodium, which can destroy the soil structure owing to dispersion of clay particles (Singh 2002). SAR was computed using the equation given below (Richard 1954):

$\mathrm{SAR}=\left(\mathrm{Na}^{+}\right) /\left[\left(\mathrm{Ca}^{2+}+\mathrm{Mg}^{2+}\right) / 2\right]^{1 / 2}$,

where the concentrations are reported in meq/l.

The SAR values ranged from 0.71 to 6.95 with a mean varying from value of $1.16 \pm 0.36$ to $3.58 \pm 1.97$ in the three groups (Table 3). All samples fall in low sodium class (S1) (Table 4). This implies that no alkali hazard is anticipated to the crops. If the SAR value is greater than $6-9$, the irrigation water will cause permeability problems on shrinking and swelling of clayey soils types (Saleh et al. 1999).

The SAR and electrical conductivity values plotted on the US salinity diagram (Richards 1954) illustrate that most of the groundwater samples of the group 1 belong to the categories C2S1 (medium salinity and low sodium) and C3S1 (high salinity and low sodium or alkali) (Fig. 5). All samples of the group 2 and most samples of the group 3 fall in the field of $\mathrm{C} 3 \mathrm{~S} 1$, indicating high salinity and low

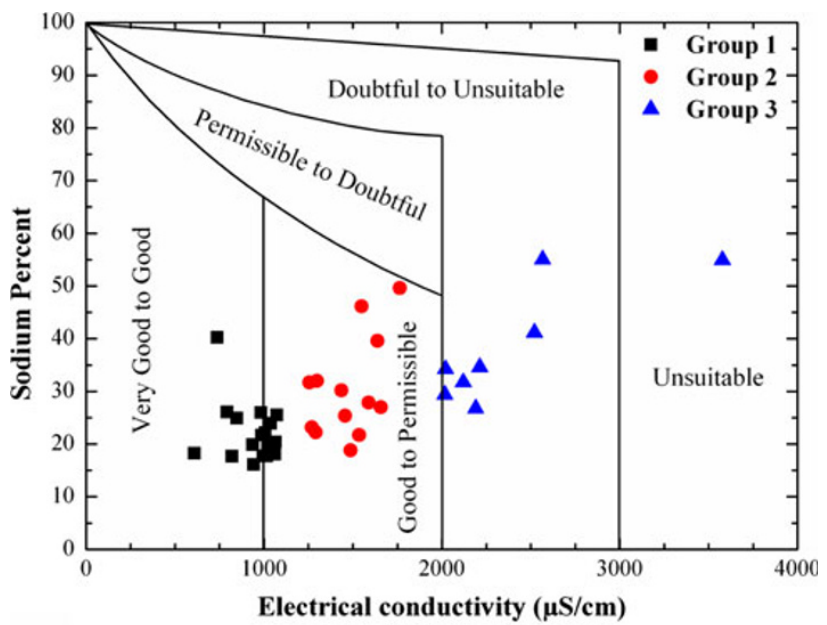

Fig. 5 Wilcox diagram for well waters

Table 4 Alkalinity hazard classes of groundwater

\begin{tabular}{|c|c|c|c|c|c|c|c|c|}
\hline \multirow[t]{2}{*}{ SAR } & \multirow[t]{2}{*}{ Alkalinity hazard } & \multirow[t]{2}{*}{ Water class } & \multicolumn{3}{|c|}{ Representing wells } & \multicolumn{3}{|c|}{ Total no. of wells } \\
\hline & & & Group 1 & Group 2 & Group 3 & Group 1 & Group 2 & Group 3 \\
\hline$<10$ & $\mathrm{~S} 1$ & Excellent & All wells & All wells & All wells & 17 & 13 & 08 \\
\hline $10-18$ & $\mathrm{~S} 2$ & Good & Nil & Nil & Nil & Nil & Nil & Nil \\
\hline $18-26$ & $\mathrm{~S} 3$ & Doubtful & Nil & Nil & Nil & Nil & Nil & Nil \\
\hline$>26$ & S4 & Unsuitable & Nil & Nil & Nil & Nil & Nil & Nil \\
\hline
\end{tabular}


Table 5 Suitability of groundwater for irrigation based on percent sodium

\begin{tabular}{|c|c|c|c|c|c|c|c|}
\hline \multirow[t]{2}{*}{$\mathrm{Na} \%$} & \multirow[t]{2}{*}{ Water class } & \multicolumn{3}{|l|}{ Representing wells } & \multicolumn{3}{|c|}{ Total no. of wells } \\
\hline & & Group 1 & Group 2 & Group 3 & Group 1 & Group 2 & Group 3 \\
\hline$<20$ & Excellent & $3-4-5-6-9-10-35-37$ & 38 & Nil & 08 & 01 & Nil \\
\hline $20-40$ & Good & $2-7-8-22-25-26-30-36$ & $\begin{array}{l}12-13-14-15-17 \\
18-20-21-33-34\end{array}$ & $11-16-19-24-31$ & 08 & 12 & 05 \\
\hline $40-60$ & Permissible & 1 & $23-28$ & $27-29-32$ & 01 & 02 & 03 \\
\hline $60-80$ & Doubtful & Nil & Nil & Nil & Nil & Nil & Nil \\
\hline$>80$ & Unsuitable & Nil & Nil & Nil & Nil & Nil & Nil \\
\hline
\end{tabular}

Table 6 Quality of groundwater based on residual sodium carbonate

\begin{tabular}{|c|c|c|c|c|c|c|c|}
\hline \multirow[t]{2}{*}{ RSC } & \multirow[t]{2}{*}{ Remark on quality } & \multicolumn{3}{|c|}{ Representing wells } & \multicolumn{3}{|c|}{ Total no. of wells } \\
\hline & & Group 1 & Group 2 & Group 3 & Group 1 & Group 2 & Group 3 \\
\hline$<1.25$ & Good & All wells & All wells & All wells & 17 & 13 & 08 \\
\hline $1.25-2.5$ & Doubtful & Nil & Nil & Nil & Nil & Nil & Nil \\
\hline$>2.5$ & Unsuitable & Nil & Nil & Nil & Nil & Nil & Nil \\
\hline
\end{tabular}

sodium water, thus they can be used for irrigation on almost all types of soil with little danger of exchangeable sodium (Fig. 5). Three samples of the group 3 fall in the field of $\mathrm{C} 4 \mathrm{~S} 2$, indicating very high salinity and medium sodium hazard. These samples will be suitable for plants having good salt tolerance and hence restricted suitability for irrigation, especially in soils with limited drainage (Karanth 1989; Mohan et al. 2000).

The sodium percentage $(\mathrm{Na} \%)$ is calculated using the formula given below, where all the concentrations are expressed in meq/l:

$\mathrm{Na} \%=\left[\left(\mathrm{Na}^{+}\right) /\left(\mathrm{Ca}^{2+}+\mathrm{Mg}^{2+}+\mathrm{Na}^{+}+\mathrm{K}^{+}\right)\right] \times 100$.

The Na \% of groundwater samples ranges from 16.12 to 55.07 with a mean of 22.14 for group 1, 30.40 in group 2 and 38.49 in group 3 (Table 3). The $\mathrm{Na} \%$ indicates that the groundwater is excellent to permissible for irrigation in the three groups (Table 5) (Ragunath 1987). The Wilcox (1955) diagram relating sodium percentage and electrical conductivity values shows that most of the groundwater samples fall in the field of good to permissible (groups 1 and 2) except a few samples falling in the fields of doubtful and unsuitable category for irrigation (group 3) (Fig. 5). When the concentration of sodium is high in irrigation water, sodium ions tend to be absorbed by clay particles, displacing $\mathrm{Mg}$ and $\mathrm{Ca}$ ions. This exchange process of $\mathrm{Na}$ in water for $\mathrm{Ca}$ and $\mathrm{Mg}$ in soil reduces the permeability and eventually results in soil with poor internal drainage. Hence, air and water circulation is restricted during wet conditions and such soils are usually hard when dry (Collins and Jenkins 1996; Saleh et al. 1999).
In addition to the SAR and $\mathrm{Na} \%$, the excess sum of carbonate and bicarbonate in groundwater over the sum of calcium and magnesium also influences the unsuitability of groundwater for irrigation. This is denoted as residual sodium carbonate (RSC), which is calculated as follows (Ragunath 1987):

$\mathrm{RSC}=\left(\mathrm{HCO}_{3}{ }^{-}+\mathrm{CO}_{3}^{-}\right)-\left(\mathrm{Ca}^{2+}+\mathrm{Mg}^{2+}\right)$,

where the concentrations are reported in meq/l.

According to the US Department of Agriculture, water having more than 2.5 of RSC is not suitable for irrigation purposes. Groundwater of the study area was classified on the basis of RSC and the results are presented in Tables 3 and 6 for the three groups. The RSC values range from -12.46 to -1.58 with a mean of $-4.14 \pm 2.58$ for the first group, from -12.53 to -4.2 with a mean of $-6.66 \pm 2.29$ for the second group and from -13 to -6.4 with a mean of $-9.38 \pm 2.41$ in the last group (Table 3). Based on RSC values, all the samples of the three groups have RSC values less than 1.25 and were considered good for irrigation (Table 6).

\section{Conclusion}

This study was conducted to evaluate factors regulating groundwater quality in an area with agriculture as main use. Thirty-eight groundwater samples have been collected from El Eulma area (Algeria) for hydrochemical investigations to understand the sources of dissolved ions and assess the chemical quality of the groundwater. Majority of the groundwater samples exhibit that the alkaline earths 
Table 7 Comparison of different indices for concrete corrosion by group water samples

\begin{tabular}{llll}
\hline & AI & LSI & RSI \\
\hline Common value of "aggressive" water & $<10$ & $<-0.5$ or $>+0.5$ & $>8$ \\
Group 1 & & & \\
Min & 12.36 & 0.08 & 6.91 \\
Max & 12.81 & 0.50 & 8.09 \\
Mean & 12.60 & 0.35 & 7.47 \\
SD & 0.15 & 0.15 & 0.36 \\
Group 2 & & & \\
Min & 12.26 & -0.03 & 7.04 \\
Max & 12.92 & 0.61 & 8.06 \\
Mean & 12.60 & 0.32 & 7.54 \\
SD & 0.18 & 0.17 & 0.29 \\
Group 3 & & & \\
Min & 12.26 & -0.09 & 6.67 \\
Max & 13.06 & 0.81 & 7.97 \\
Mean & 12.62 & 0.32 & 7.34 \\
SD & 0.27 & 0.29 & 0.42 \\
\hline
\end{tabular}

$\left(\mathrm{Ca}^{2+}+\mathrm{Mg}^{2+}\right)$ significantly exceed the alkalis $\left(\mathrm{Na}^{+}+\right.$ $\left.\mathrm{K}^{+}\right)$and weak acids exceed the strong acids $\left(\mathrm{Cl}^{-}+\mathrm{SO}_{4}^{-2}\right)$. Q-mode cluster analysis was applied to groundwater quality data sets, and generated three clusters (groups 1,2 and 3). The values of sodium absorption ratio and electrical conductivity of the ground water were plotted in the US salinity laboratory diagram for irrigation water. Most of the samples fall in C3S1 quality with high salinity hazard and low sodium hazard. Based on RSC values, all the samples were classified as suitable for irrigation (Table 7).

Open Access This article is distributed under the terms of the Creative Commons Attribution License which permits any use, distribution, and reproduction in any medium, provided the original author(s) and the source are credited.

\section{References}

APHA (1989) Standard methods for examination of water and wastewater, 17th edn. American Public Health Association, Washington, DC

APHA-AWWA-WPCF (1995a) Standard methods for the examination of water and wastewater, 19th edn. New York, USA

APHA (1995b) Standard methods for the examination of water and wastewater, 19th edn. American public Health Association, Washington, DC

Belkhiri L, Boudoukha A, Mouni L, Baouz T (2010) Application of multivariate statistical methods and inverse geochemical modeling for characterization of groundwater - A case study: Ain Azel plain (Algeria). Geoderma 159:390-398
Clesceri LS, Greenberg AE, Eaton AD (1998) Standard methods for the examination of water and wastewater, 20th edn. American Public Health Association, Washington, p 1325. ISBN:0875532357

Collins R, Jenkins A (1996) The impact of agricultural land use on stream chemistry in the middle Hills of the Himalayas, Napal. J Hydrol 185:71-86

Davis JC (1986) Statistics and data analysis in geology. Wiley, New York, p 647

Galcon J (1967) Recherches sur la géologie et les gîtes métallifères du Tell Sétifien, Doct Thesis Sc. Nat. Publ. Serv. Geol. From Algeria

Guiraud R (1973) Evolution post-triasique de l'avant pays de la chaîne Alpine de l'Algérie, d'après l'étude du bassin d'El Eulma et les régions voisines, Thèses Sc. Nat. Nice, France

Handa BK (1964) Modified classification procedure for rating irrigation waters. Soil Sci 98:264-269

Handa BK (1965) Modified Hill-piper diagram for presentation of water analysis data. Curr Sci 34:131-314

Hem JD (1985) Study and interpretation of the chemical characteristics of natural water. USGS Water Supply Paper 2254:117-120

Karanth KR (1989) Hydrogeology. McGraw-Hill, New Delhi

Kelley WP (1940) Permissible composition and concentration of irrigation waters. Proc ASCE 66:607

Mohan R, Singh AK, Tripathi JK, Chowdhary GC (2000) Hydrochemistry and quality assessment of ground water in Naini Industrial area, Allahabad District, Uttar Pradesh. J Geol Soc Ind 55:77-89

Ragunath HM (1987) Groundwater. Wiley, New Delhi, p 563

Richard LA (1954) Diagnosis and improvement of saline and alkali soils. Agricultural handbook, vol 60. USDA, Washington, DC, p 160

Rowell DJ (1994) Soil science: methods and applications. Longman Scientific and Technical, London

Saleh A, Al-Ruwih F, Shehata M (1999) Hydrogeochemical processes operating within the main aquifers of Kuwait. J Arid Environ 42:195-209

Savornin J (1920) Etude géologique du Hodna et du plateau Sétifien, Thèse Sc. Nat. Lyon, France

Singh AK (2002) Quality assessment of surface and sub-surface water of Damodar river basin, India. J Environ Health 44:41-49

STATISTICA $^{\circledR} 5.0$ for Windows (1998) USDA, Natural Resources Conservation Services, 1999. Soil taxonomy: a basic system of soil classification for making and interpreting soil surveys. Agriculture handbook, vol 436. StatSoft, Inc., Tulsa, p 871

Swanson S, Bahr J, Schwar M, Potter K (2001) Two-way cluster analysis of geochemical data to constrain spring source waters. Chem Geol 179:73-91

USSL (1954) Diagnosis and improvement of saline and alkali soils, handbook, vol 60. USDA, Washington, p 147

Vila JM (1980) La chaîne Alpine d'Algérie orientale et des confins Algéro-Tunisiens, Thesis of doctorate be-Sc. Nat. Paris VI, France

WHO (2006) Guidelines for drinking-water quality. Recommendations, vol 1, 3rd edn. Word Health Organization, Geneva

Wilcox LV (1948) The quality of water for irrigation use. Technical bulletin, vol 962. U.S. Department of Agriculture, Washington, DC, $\mathrm{p} 40$

Wilcox LV (1955) Classification and use of irrigation waters, vol 969. U.S. Department of Agriculture Circular, Washington, DC, p 19 